\title{
DECOMPOSITION OF UNEMPLOYMENT IN RURAL POPULATION ON THE BASIS OF MAIN SOURCES OF INCOME IN 2002-2009 AND 2016
}

\author{
Włodzimierz Kołodziejczak, $\mathrm{PhD}^{1}$
}

Faculty of Economics and Social Sciences, Poznań University of Life Sciences

\begin{abstract}
The aim of the paper is to present a decomposition of unemployment in the rural population into the structural and cyclical components in groups distinguished based on their main source of household income. This study was conducted using the method estimating the level of natural unemployment (equilibrium unemployment) proposed by the Centre for Economic Policy Research (1995). The analysis was based on individual, unweighted, quarterly raw data provided by the Polish LFS (BAEL) from the years 2002-2009 and 2016. The professional situation of the rural population in the analysed period improved, which was manifested in an increase in the employment rate and a reduction of the actual unemployment rate. Between the periods of 2002-2005 and 2006-2009 actual unemployment 'followed' the lower values of equilibrium unemployment. In 2016 the actual unemployment rate was lower than in previous periods; however, an adverse change was observed for its relation to the natural unemployment rate. If we assume that it will - as previously - strive to attain the equilibrium level, in the case of a downturn on the market for goods and services the actual unemployment among the rural population may considerably increase, particularly in the group of individuals whose main source of income is provided by unemployment benefits and the family farm.
\end{abstract}

Keywords: natural unemployment, labour flows, rural population

JEL codes: J20, J63

\section{INTRODUCTION}

Literature sources on the subject distinguish two basic directions in the discussion of the phenomenon of unemployment. Representatives of one direction perceive the causes of high unemployment in Poland in structural discrepancies between demand for labour and its supply. Proponents of this theory postulate that in order to reduce the scale of unemploy- ment it is necessary deregulate the labour law to the advantage of employers and to lower or eliminate minimum salaries (Friedman, 1957; Wilczyński, 2003), which by principle is to result in a shift of equilibrium on the labour market towards high employment rates, and to increase competitiveness of the Polish economy. The other direction stresses the effect of factors connected with the current situation on the market for goods and services. Supporters

${ }^{1}$ Corresponding author: Wojska Polskiego 28,60-637 Poznań, Poland, kolodziejczak@up.poznan.pl, +4861 8467305 
of this approach indicate the advisability of active instruments of the exchange rate, customs and fiscal policies, which should contribute to increased employment in a given country (Keynes, 1956; Kabaj, 2003). However, unemployment is typically a complex phenomenon of structural and cyclical character, which means that it is necessary to apply simultaneously methods to control it, which are adequate to each of its components. Determination of the relations between actual and structural unemployment not only facilitates selection of proper tools on the labour market, but also makes it possible to predict how the situation on the labour market will be changing in the case of an improvement or deterioration of the situation on the market for goods and services.

The aim of this paper is to present a decomposition of unemployment in the rural population into the structural and cyclical components, in groups distinguished based on the main source of household income. The calculations made it possible to indicate vulnerability of individual groups in the rural population to changes in the economic situation and to the effects of structural factors (including institutional factors), and as a consequence - provided grounds for inference on the threat of unemployment or professional disactivation.

\section{THEORETICAL BACKGROUND}

A method to estimate the size of the structural and cyclical components of unemployment consists in the determination of the level of steady-state equilibrium unemployment, i.e. such which the economy is striving to attain over a long period. In this approach the level of unemployment below the equilibrium level is equivalent to the structural component (over a short period generally resistant to changes in the economic situation), while the section of unemployment above the equilibrium level is connected with the cyclical component (i.e. occurring as a result of too low demand for labour).

Socha and Sztanderska (2002) after Haltiwanger (1991) stated that equilibrium unemployment refers to such a level of unemployment, which a dynamic system strives to attain under the stochastic general equilibrium conditions. It takes into consideration actual, structural characteristics of the labour markets and markets for goods, including market inefficiencies as well as costs associated with searching for a job and mobility costs. In simple terms we may assume that equilibrium unemployment is modified by the effects of the skill-wage mismatch (excessive wage expectations of the labour force in relation to the offer of employers under specific economic conditions), as well as the mismatch concerning qualitative and spatial characteristics of the labour force and vacancies (age, sex, education, location, skills, motivation, certificates and licences, etc.) (Kwiatkowski, 2002; Socha and Sztanderska, 2002). This phenomenon is observed even at the maintenance of equilibrium between the aggregate supply of the labour force and the aggregate demand for labour over the entire market. Causes of the mismatches include wage rigidity and wage expectations, institutional limitations, technological progress, geographical distribution of labour and vacancies as well as structural changes in the economy (Jackman and Roper, 1987; Socha and Sztanderska, 2002; Kołodziejczak and Wysocki, 2013).

Determination of the steady-state unemployment level makes it possible to estimate what part of unemployment observed in the economy is independent of short-term cyclical fluctuations on the markets for goods and services (Socha and Sztanderska, 2002), i.e. what part of unemployment is structural in character and what part is cyclical. This information is the basis for the determination of the type of actions aiming to increase employment and/or reduce unemployment - a high rate of structural unemployment in actual unemployment is an impulse to implement programmes to improve the matching of the supply and demand sides of the labour market and to eliminate non-cyclical barriers (including wage-related) limiting employment, while a considerable share of cyclical (Keynesian) unemployment indicates advisability of stimulation of economic growth. 


\section{MATERIALS AND METHODS}

This study applies the method to estimate the level of natural (equilibrium) unemployment proposed by the Centre for Economic Policy Research (1995)2. The analysis was based on individual, unweighted, quarterly raw data provided by the Polish LFS (BAEL) from the years 2002-2009 and 2016 ${ }^{3}$. Changes in the economic activity of individuals were observed in panels - pairs of quarters, in which among the entire LFS sample only those individuals were considered, who were surveyed in both quarters of a given pair (e.g. the $1^{\text {st }}$ and the $2^{\text {nd }}$ quarters of 2002 , next the $2^{\text {nd }}$ and the $3^{\text {rd }}$ quarters of 2002 , the $3^{\text {rd }}$ and the 4 th quarters of 2002 , the 4 th quarter of 2002 and the $1^{\text {st }}$ quarter of 2003, etc.).

The analyses were based on 16 unpublished, individual, quarterly sets of LFS raw data from the years 2002-2005, sixteen sets from the years 2006-2009 and four sets from 2016. In each quarter analyses were conducted (depending on the LFS surveyed population size) on min. 44 thousand individuals in the years 2002-2005, 80 thousand individuals in the years 2006-2009 and approx. 100 thousand individuals in 2016. Among the many investigated classification sections (e.g. age, sex, education, place of residence, type of town of their residence, links with agriculture, etc.) the paper presents results obtained for two criteria applied simultaneously, i.e. types of place of residence and the main source of household income. As the calculations were performed on unweighted data (it is the only possible approach in re- lation to the LFS individual database in the BAEL system, since weights ascribed to respondents by the Main Statistical Office (GUS) are proper only for the entire sample and are not applicable to individual population groups), the results need to be treated as approximate values. Their informative value consists in the indication of differences and potential trends; however, they may not be treated as accurate actual values.

Based on the LFS (BAEL) data the volume and rates of flows were determined between individual types of economic activity status in the population on average in the years 2000-2005, 2006-2009 and in 2016. As a result it was possible to apply the equilibrium unemployment estimation method developed by the Center for Economics Policy Research - CEPR (1995). The CEPR method consists in the determination of the steady-state unemployment rate according to the formula:

$$
u^{*}=\frac{s+z}{s+h+n}
$$

where:

$u^{*}$ - equilibrium (steady-state) unemployment rate, $s=(E U+E N) / E-$ rate of outflow from employment (including to unemployment and economical inactivity),

$h=U E / U-$ rate of outflow from unemployment to employment,

$z=(N U-U N-E N) /(E+U)-$ demographic component of unemployment,

\footnotetext{
${ }^{2}$ Depending on the applied method estimating equilibrium unemployment they may be determined for the entire economy or for individual groups of the population distinguished based on selected characteristics. Models based on the Philips Curve theory or on the hypothesis of rational expectations and neutrality of money, e.g. NAIRU (Non-Accelerating Inflation Rate of Unemployment) and NAWRU (Non-Accelerating Wage Rate of Unemployment) use market variables and their application is limited generally to aggregate data at the level of whole economies (Socha and Wojciechowski, 2004). Methods based on the analysis of changes in behaviour of individuals on the labour market make it possible to analyse separately groups of the population differing in socio-economic characteristics. The most important of these include the method proposed by the Center for Economics Policy Research (1995), the Gärtner method (1997) and the method proposed by Darby, Haltiwanger and Plant (1986).

${ }^{3}$ The period 2002-2005 can be considered as the time of the agreed 'end of transformation' and stabilization of the structure of the economy with simultaneous high unemployment. The years 2006-2009 showed the improvement of the situation, resulting in a negative external shock that revealed as the 2007-2009 financial crisis (Kołodziejczak and Wysocki, 2015). The year of 2016 is a period of noticeable improvement in the labour market, resulting mainly from economic growth and demographic trends (and at the same time the latest LFS data available to the author).
} 
$n$ - percentage changes in labour force resources in the assumed sample duration,

while:

E - the number of employed at the beginning of the investigated period,

$\mathrm{U}$ - the number of unemployed at the beginning of the investigated period,

EU - the volume of flows from employment to unemployment in the analysed period (the number of individuals, who changed their status from employed to unemployed),

EN - the volume of flow from the group of employed to the group of economically inactive,

$\mathrm{NU}$ - the volume of flow from the group of economically inactive to the group of unemployed,

$\mathrm{UN}$ - the volume of flow from the group of unemployed to the group of economically inactive,

UE - the volume of flow from the group of unemployed to the group of employed.

If $u^{*}>u$, actual unemployment $(u)$ will probably increase, since it did not yet reach the level resulting from the effect of structural factors on the labour market (mismatch of supply and demand for labour); if $u^{*}<u$, actual unemployment is greater than that resulting from structural factors and the difference may be approximately treated as equivalent to unemployment caused by a too slow economic growth (thus probably values $u$ may approach level $u *$ by stimulating the economic prosperity on the market for goods and services). The analysis of changes in values of these indexes for individual groups of the population distinguished from the labour resources or for individual markets makes it possible to determine causes for adverse phenomena, identify problem groups at risk of unemployment and propose directions for corrective actions ${ }^{4}$.

\section{RESULTS AND DISCUSSION}

Table 1 presents characteristics of economic activity for the rural population in Poland in terms of the main source of income in the years 2002-2005, 2006-2009 and 2016 (average values in the periods). It may be stated that with time the actual unemployment rate was decreasing in all the investigated groups of the population. This fact and the increasing values of the employment rate indicate improvement in the situation on the labour market. Only among individuals whose main source of income is the running of the family farm the employment rates were decreasing slightly in 2016 in relation to the years 2006-2009; however, the observed difference may be considered to fall within the error of measurement value. Steadystate unemployment rate in the years 2006-2009 in all the groups was lower than in the years 2002-2005. This indicates a decreasing importance of the structural component of unemployment, which may indirectly suggest a reduced role of the qualitative mismatch between labour demand and supply, but - in relation with the decrease in the values of the actual unemployment rate - also the equilibrium unemployment rate following the decreasing actual unemployment. Nevertheless, estimates for 2016 indicate - at least a partial - reversal of this trend.

The overall equilibrium unemployment rate in rural areas was almost two-fold greater in 2016 than in the years 2006-2009, mainly due to the rapid increase in its values among individuals classified to households supported mainly by unemployment benefits (Table 1). While in the earlier periods unemployment in this group could be linked to a considerable extent to the general shortage of jobs, in 2016 almost 50\% of the actual unemployment was structural. It may be explained in two ways: firstly, an improvement overall situation on the labour market after 2004, connected among other things with economic migra-

\footnotetext{
${ }^{4}$ It needs to be stressed that they are oversimplifications and the interpretation of the results based on these assumptions has to take into consideration economic and social conditions. However, it is worthwhile to accept them in view of their usefulness. Limitations observed in this respect result first of all from the mechanisms of hysteresis on the labour market (cf. Layard, Nickell and Jackman, 1991; Kołodziejczak and Wysocki, 2013).
} 
Proceedings of the 2018 International Scientific Conference 'Economic Sciences for Agribusiness and Rural Economy' No 2, Warsaw, 7-8 June 2018, pp. 102-108

Table 1. Characteristics of economic activity in the rural population in Poland in terms of the main source of income in 2002-2009 and 2016 (means in periods)*

\begin{tabular}{|c|c|c|c|c|c|c|}
\hline Area & Years & $\begin{array}{c}\text { Economic } \\
\text { activity index }\end{array}$ & $\begin{array}{l}\text { Employment } \\
\text { rate }\end{array}$ & $\begin{array}{l}\text { Actual } \\
\text { unemployment } \\
\text { rate }\end{array}$ & $\begin{array}{l}\text { Equilibrium } \\
\text { unemployment } \\
\text { rate according } \\
\text { to CEPR }\end{array}$ & $\begin{array}{c}\text { Actual } \\
\text { unemployment } \\
\text { to equilibrium } \\
\text { unemployment } \\
\text { ratio }\end{array}$ \\
\hline \multirow{3}{*}{ Total for rural areas } & $2002-2005$ & 53.9 & 44.6 & 17.4 & 14.1 & 81.3 \\
\hline & 2006-2009 & 52.0 & 47.5 & 8.6 & 5.1 & 59.3 \\
\hline & 2016 & 51.2 & 48.0 & 6.1 & 10.1 & 163.7 \\
\hline \multirow{3}{*}{$\begin{array}{l}\text { Agricultural family } \\
\text { farm }\end{array}$} & $2002-2005$ & 69.0 & 65.2 & 5.8 & 5.1 & 89.2 \\
\hline & 2006-2009 & 67.9 & 66.0 & 2.9 & 2.3 & 80.3 \\
\hline & 2016 & 67.2 & 65.4 & 2.6 & 5.3 & 203.3 \\
\hline \multirow{3}{*}{ Employees } & $2002-2005$ & 60.4 & 48.8 & 19.8 & 8.5 & 43.0 \\
\hline & 2006-2009 & 56.2 & 49.9 & 11.7 & 3.8 & 32.2 \\
\hline & 2016 & 59.4 & 57.0 & 4.0 & 1.9 & 46.3 \\
\hline \multirow{3}{*}{$\begin{array}{l}\text { Self-employed, } \\
\text { excluding the } \\
\text { running of a private } \\
\text { farm in agriculture }\end{array}$} & $2002-2005$ & 64.5 & 57.6 & 10.8 & 21.2 & 196.2 \\
\hline & 2006-2009 & 63.2 & 60.3 & 4.6 & 3.3 & 70.6 \\
\hline & 2016 & 73.6 & 71.6 & 2.7 & 0.3 & 10.1 \\
\hline \multirow{3}{*}{$\begin{array}{l}\text { Unemployment } \\
\text { benefits }\end{array}$} & 2002-2005 & 54.5 & 15.6 & 70.8 & 28.2 & 39.9 \\
\hline & 2006-2009 & 47.0 & 12.9 & 71.7 & 2.5 & 3.5 \\
\hline & 2016 & 59.0 & 41.7 & 29.5 & 47.6 & 161.4 \\
\hline
\end{tabular}

* due to the marginal importance of the risk of unemployment and the limited size of this paper the presented results exclude groups of individuals with income received but not earned: disability pensions, old age pensions and others (excluding unemployed).

Source: the author's calculations based on unpublished, individual quarterly raw data of Polish LFS (BAEL).

tion abroad for the population from areas suffering the most from unemployment, which eliminated a considerable part of the cyclical component of unemployment. Secondly, the remaining unemployed rural population retained their professional situation as a result of institutional regulations (e.g. subsidies to unprofitable farms, stricter regulations concerning temporary employment, social aid programmes) and - probably - a lack of economic justification for undertaking employment at the offered wages. Another group, among which steady-state employment increased included individuals classified to households supported by the running of the family farm. In this case the causes may be similar to those indicated for the previous group, i.e. migration abroad and subsidies to unprofitable farms. It may be assumed that in both groups individuals better adapted to the needs stated by employers undertook employment in Poland or abroad, while the group of unemployed was composed of those less adapted to the requirements and new individuals classified to that group from among those economically inactive. A certain effect on the increase in the level of equilibrium unemployment may have also been connected with the unemployment revealed by reducing hidden unemployment in agriculture (Kołodziejczak, 2016).

A disturbing finding is connected with the considerable increase in the ratio of the equilibrium un- 
employment rate and the actual unemployment rate recorded in 2016 in relation to the years 2006-2009. On average in the rural areas is was almost $164 \%$, among individuals in households supported mainly by unemployment benefits it was over $161 \%$, while in the group of individuals in households supported mainly by running a family farm it was as high as over $203 \%$. Assuming that actual unemployment follows equilibrium unemployment, it indicates potential, marked and adverse changes in the professional situation of the population in those groups at a decline on the market for goods and services. It also points to mostly cyclical/demand causes of a relatively good situation on the labour market (it is possible that to a large extent they are artificially created as a result of both intervention and social programs and the transfer of EU assistance funds). At the same time, it is likely that this situation does not have strong structural foundations. It means that without sustaining market intervention (mostly through money transfers for the population and institutions), the real unemployment rate will be significantly increased.

\section{CONCLUSIONS}

The aim of this paper was to deconstruct the phenomenon of unemployment in the rural population into the structural and cyclical components in groups distinguished in terms of the primary source of household income. The investigations showed that the professional situation of the rural population in the analysed period improved, which was manifested in an increase in the values of the employment rate at a reduction of the actual unemployment rate. Between the periods 2002-2005 and 2006-2009 actual unemployment followed lower values of equilibrium unemployment. In 2016 the actual unemployment rate was lower than in earlier periods; however, its relation to the steady-state unemployment rate was deteriorating. If we assume that it will - as previously - attempt to reach the equilibrium level, in the case of a decline on the market for goods and services actual unemployment among the rural population may increase considerably, particularly in the group of individuals in households supported mainly from unemployment benefits and operation of family farms.

\section{Acknowledgements}

The paper is funded by the National Science Centre within the MINIATURA research project NCN DEC-2017/01/X/HS4/00565, entitled 'Determinants of Economic Activity of the Rural Population in Poland. Opportunities to reduce hidden unemployment in agriculture' (Polish version: Determinanty aktywności ekonomicznej ludności wiejskiej w Polsce. Możliwości redukcji bezrobocia ukrytego w rolnictwie).

\section{REFERENCES}

1. CEPR (1995). Unemployment: Choices for Europe. London.

2. Darby, M., Haltiwanger, J., Plant, M. (1986). Unemployment Rate Dynamics and Persistent Unemployment under Rational Expectations. American Economic Review, 75 (4), pp. 1-55.

3. Friedman, M. (1968). The Role of Monetary Policy. American Economic Review, 75 (1), pp. 1-17.

4. Gärtner, M. (1997). A Primer in European Macroeconomics. Prentice Hall, London.

5. Haltiwanger, J. (1991). The natural Rate of Unemployment. In: A Dictionary of Economics. Vol. 3. Macmillan Press LTD, London, p. 357.

6. Indywidualne, nieważone, kwartalne dane surowe BAEL (Polish LFS) z lat 2002-2009 i 2016 [Individual, unweighted, quarterly raw data from Polish LFS (BAEL) for the years 2002-2009 and 2016].

7. Jackman, R., Roper, R. (1987). Structural Unemployment,. Oxford Bulletin of Economics Performance Discussion Papers 349, pp. 9-36

8. Kabaj, M. (2003). Mechanizmy tworzenia i likwidacji miejsc pracy w polskiej gospodarce. Jak utworzyć 2 miliony nowych miejsc pracy do $2010 \mathrm{r}$. [Mechanisms for the creation and liquidation of jobs in the Polish economy. How to create 2 million new jobs by 2010]. In: Proceedings from the meeting of the Social and Economic Council, Warszawa.

9. Keynes, J.M. (2003). The General Theory of Employment, Interest and Money. Wydawnictwo Naukowe PWN, Warszawa.

10. Kołodziejczak, W. (2016). Hidden unemployment in Polish agriculture in 1995-2015. Journal of Agribusiness and Rural Development, 4 (42), pp. 545-556.

11. Kołodziejczak, W., Wysocki, F. (2013). Identyfikacja charakteru bezrobocia w Polsce w latach 2006-2009 [Identification of the character of unemployment in 
Poland in the years 2006-2009]. Gospodarka Narodowa, 9, pp. 29-52

12. Kołodziejczak, W., Wysocki, F. (2015). Determinanty aktywności ekonomicznej ludności wiejskiej w Polsce [Determinants of economic activity of the rural population in Poland]. Wyd. UP w Poznaniu, Poznań.

13. Kwiatkowski, E. (2002). Bezrobocie. Podstawy teoretyczne [Unemployment. Theoretical background]. Wydawnictwo Naukowe PWN, Warszawa.

14. Layard, R., Nickell, S., Jackman, R. (1991). Unemployment. Macroeconomics Performance and the Labour Market. Oxford University Press, Oxford-New York.

15. Socha, M., Sztanderska, U. (2002). Strukturalne podstawy bezrobocia w Polsce [Structural background of unemployment in Poland]. Wydawnictwo Naukowe PWN Warszawa.

16. Socha, M., Wojciechowski, W. (2004). Koncepcja NAIRU, dezinflacja a druga fala bezrobocia w Polsce [The NAIRU concept, disinflation and the second wave of unemployment in Poland]. Bank i Kredyt, March, pp. 4-15.

17. Wilczyński, W. (2003). Determinanty problemów rynku pracy w okresie transformacji ustrojowej. Rynek pracy w warunkach zmian ustrojowych [Determinants of problems on the labour market in the period of political transformation. The labour market in view of political changes]. In: Proceedings from the Scientific Symposium of the Poznań University of Economics, Poznań, 06.12.2003. 